\title{
Effective use of innovative technologies in mixed sowing of annual crops
}

\author{
E. Yu. Podlasova*, and S. V. Lebedev \\ Federal Research Centre for Biological Systems and Agricultural Technologies of the Russian \\ Academy of Sciences, Orenburg, Russia
}

\begin{abstract}
It is impossible to organize proper feeding of farm animals without a detailed study of the composition of the nutritional content of feed. Legume-grass mixtures occupy one of main places in solving the problem of high-quality feed production. Since mixed crops of legumes and cereals retain high fodder quality of green mass due to high protein content in legumes. To meet the need for a high-quality feed base, it is necessary to look for ways to increase the yield of fodder crops. The use of innovative technologies is one of the components of modern crop production. The aim of the study was to study the methods of seed treatment in conjunction with the technology of mixed crops; it allows obtaining a green mass with the desired productive properties. Thus, the article presents the materials of a field study on the development of a highly productive green feed. The results of the study of combined and mixed crops on the nutritional value and productivity of annual forages of peas, millet, and barley using pre-sowing seed treatment with ultrafine particles of $\mathrm{SiO} 2 ; \mathrm{MoO} 2 ; \mathrm{Fe} 3 \mathrm{O} 4$ and growth regulators AgroVerm and RibavExtra were obtained. As a result of the experiment, it was shown that the use of pre-sowing treatment of seeds with ultradispersed $\mathrm{SiO} 2$ particles in combined crops showed the maximum leaf surface area of 85.5 thousand $\mathrm{m} 2 / \mathrm{ha}$. By the time of harvesting, the safety of plants on variants with the use of $\mathrm{SiO} 2 ; \mathrm{Fe} 3 \mathrm{O} 4 ; \mathrm{MoO} 2$ was $88.4 \% ; 87.5 \%$; $86.5 \%$ respectively. According to the collection of digestible protein, variant with the use of ultrafine particles $\mathrm{SiO} 2$ was $20 \%$ in both sowing methods. Low protein content was $16.1 \% ; 16.4 \%$ in the control variants respectively. According to the content of feed units in $1 \mathrm{~kg}$ of dry matter, $\mathrm{SiO} 2$ variants prevail with 0.91 . Thus, the research is the basis for possible studying of combined and mixed crops with the use of pre-sowing seed treatment with ultrafine particles. It allows obtaining high-quality feed.
\end{abstract}

\section{Introduction}

To increase the production of high-quality complete feed, multi-species crops play the main role. The main source of high-quality green forage is the annual sowing of leguminous crops. We obtain different and the cheapest fodder from them. Sowing with a mixture of leguminous crops provides more stable yields, since the decrease in the yield of one crop compensates in another.

\footnotetext{
*Corresponding author: katerina.pryakhina@mail.ru
} 
With the development of nanotechnology, science and technology are connected with a wide variety of areas of human activity. With the extensive development of innovative technologies, nanometals acquire new properties and biological effects that were not inherent in them, penetrate into cell and nucleus, increase bioavailability. [1]. In addition, the unique properties of ultrafine particles and their use in scientific and technical field have recently enriched this area of research. [2]. The development of agricultural production is an excellent task in agriculture with a minimum use of agrochemicals taking into account the conditions of growth and plant protection.

Ultrafine particles of iron oxide influence on growth and content of chlorophyll in corn plants [3]. Pretreating seeds with $\mathrm{ZnO}$ can alter the nutrient content of seeds; it affects plant growth, yield and quality. [4] In addition, ultrafine particles of copper and zinc helped to increase the resistance of two wheat varieties at the seedling stage by stabilizing photosynthetic pigments, thereby increasing the water content in the leaves. [5]

To some extent, high or low concentrations of ultrafine particles have opposite functions in plant development, they can inhibit or stimulate the plant. [6].

\section{Study objective}

Thus, the use of pre-sowing seed treatment in conjunction with the technology of mixed crops will allow to obtain green mass with the desired properties and productivity.

\section{Materials and methods}

Field test research was carried out in 2020 in the central zone of Orenburg region in village Nezhinka. The experiment studied the sowing of mixtures of annual forages (peas "Yamal" + barley "Natali" + millet "Orenburgskoe 27" in a ratio of 1:2:1) with combined and mixed sowing. The experiments were made in 4 repetitions, the site was randomized, the rigistered plot area was $1 \mathrm{~m}^{2}$. In combined sowing, crops were in alternating rows or stripes. Before sowing, seeds were not mixed, but were sown separately with a row spacing of $15 \mathrm{~cm}$. The following seed treatments were studied: $\mathrm{SiO} 2$ UFPs with a size of $30.7 \pm 0.3 \mathrm{~nm}$ and a $\zeta$ potential of $27 \pm 0.12 \mathrm{mV}$, MoO2 NPs (100-120 nm) produced by Plasmoterm (Russia,

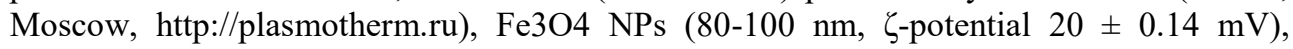
purchased from Advanced Powder Technologies (Tomsk, Russia, www.nanosizedpowders.com). Microfertilizer consumption was $100 \mathrm{~g} /$ ton. In the experiment, we used preparations based on biohumus AgroVerm ("Biokenetics" http://rusgumus.ru/) at a dose of 11 per 1 ton; Ribav Extra (https://www.agroxxi.ru/goshandbook/prep/ribav-ekstra-p-2.html) at a dose of $10 \mathrm{ml}$ per $1 \mathrm{t}$. The seeds of the mixture components were sown in rows with premixed seeds. The components are mixed at the moment of treatment with ultrafine particles of $\mathrm{SiO} 2$ with a size of $30.7 \pm 0.3 \mathrm{~nm}, \mathrm{MoO} 2 \mathrm{NPs}(100-120 \mathrm{~nm}), \mathrm{Fe} 3 \mathrm{O} 4 \mathrm{NPs}(80-100 \mathrm{~nm}, \zeta-$ potential $20 \pm 0.14 \mathrm{mV}$ ). Concerning mixed seeds, the sowing rate is calculated for each component separately. Laboratory analysis was performed in 4 repetitions. Statistical processing of data was carried out in an Excel program. The data obtained are presented as arithmetic mean values for each option.

\section{Results and discussion}

The main condition for the formation of highly productive agrophytocenoses is the creation of an optimal plant density. It has a significant effect on growth processes, plant height, and yield structure [8]. The emergence of seedlings was registered 8-11 days after sowing. More even shoots were observed when ultrafine particles of $\mathrm{SiO} 2$ and $\mathrm{MoO} 2$ were used 8-9 days 
after sowing, the condition for the formation of high fodder productivity is the formation of optimal plant density, it has a significant effect on growth processes, plant height and weight, crop structure, timing of the phases growth. Pretreatment of seeds with ultrafine particles and growth regulators promoted an increase in the number of preserved plants by the time of harvest as compared to the control. Plant safety using SiO2; Fe3O4; MoO2 was 88.4\%; $87.5 \% ; 86.5 \%$ respectively.

Table 1. Density of standing and height of plants in mixed crops of annual forages.

\begin{tabular}{|l|l|c|c|c|c|}
\hline Varant & $\begin{array}{l}\text { Sowing } \\
\text { date }\end{array}$ & $\begin{array}{l}\text { Average number of } \\
\text { plants at } \\
\text { germination, pcs /m2 }\end{array}$ & $\begin{array}{l}\text { Density of standing of } \\
\text { plants before } \\
\text { harvesting, pcs / m2 }\end{array}$ & $\begin{array}{l}\text { Plant } \\
\text { safety, } \\
\%\end{array}$ & $\begin{array}{l}\text { Height of } \\
\text { plants, cm }\end{array}$ \\
\hline \multicolumn{7}{|c|}{ Combined sowing (peas + millet + barley) } \\
\hline $\mathrm{SiO}_{2}$ & 08.05 & $93+169+236$ & $82+158+200$ & 88,4 & $44+40+73$ \\
\hline $\mathrm{MoO}_{2}$ & 08.05 & $96+166+240$ & $81+149+204$ & 86,5 & $42+39+75$ \\
\hline $\mathrm{Fe}_{3} \mathrm{O}_{4}$ & 08.05 & $92+170+242$ & $78+145+218$ & 87,5 & $40+37+72$ \\
\hline Agroverm & 08.05 & $93+162+233$ & $76+147+212$ & 89 & $40+34+72$ \\
\hline $\begin{array}{l}\text { Ribav } \\
\text { Extra }\end{array}$ & 08.05 & $90+153+229$ & $71+128+211$ & 86 & $29+33+65$ \\
\hline Control & 08.05 & $80+150+228$ & $60+125+204$ & 84 & $29+35+62$ \\
\hline \multicolumn{7}{|c|}{ Mixed sowing (peas + millet + barley) } \\
\hline $\mathrm{SiO}_{2}$ & 08.05 & $57+61+172$ & $40+52+144$ & 81,4 & $43+41+74$ \\
\hline $\mathrm{MoO}_{2}$ & 08.05 & $61+50+169$ & $48+41+139$ & 81,4 & $41+40+70$ \\
\hline $\mathrm{Fe}_{3} \mathrm{O}_{4}$ & 08.05 & $50+75+166$ & $35+66+140$ & 82,8 & $40+33+70$ \\
\hline $\mathrm{Control}^{2}$ & 08.05 & $45+75+162$ & $33+46+124$ & 71,9 & $29+33+60$ \\
\hline
\end{tabular}

Note: $*$ - Differences with control are significant at $\mathrm{p} \leq 0.05$

By the time of mowing ripeness at combined sowing, the average height of plants after seed treatment with $\mathrm{SiO} 2$ and $\mathrm{MoO} 2$ reached a height of 42-44 for peas, 39-40 for millet, and 73-75 for barley. The maximum height for mixed sowing was registered in variants with $\mathrm{SiO} 2$; pea was 43 , millet was 41 , barley was 74 . Control both in combined and mixed sowing was characterized by the lowest height among the studied variants, it was 29 for peas; 33-35 for millet; 60-62 for barley, respectively.

Table 2. Leaf surface area of sowing according to the variants of the experiment, thousand $\mathrm{m} 2 / \mathrm{ha}$.

\begin{tabular}{|c|c|c|c|c|}
\hline \multirow[t]{2}{*}{ Harvest } & \multicolumn{2}{|c|}{ Yield } & \multicolumn{2}{|c|}{ Harvest } \\
\hline & $\begin{array}{c}\text { Green weight } \mathrm{t} / \\
\text { ha }\end{array}$ & $\begin{array}{c}\text { Dry substance } t \\
/ \text { ha }\end{array}$ & feed units & protein $\%$ \\
\hline \multicolumn{5}{|c|}{ Combined sowing } \\
\hline $\mathrm{SiO}_{2}$ & $24,8 \pm 1,3$ & $4,9 \pm 0,12$ & $0,91 \pm 0,016$ & $20,2 \pm 1,09$ \\
\hline $\mathrm{MoO}_{2}$ & $23,7 \pm 1,7$ & $4,7 \pm 0,15$ & $0,89 \pm 0,011$ & $17,04 \pm 1,08$ \\
\hline $\mathrm{Fe}_{3} \mathrm{O}_{4}$ & $22,7 \pm 1,6$ & $5,1 \pm 0,12$ & $0,88 \pm 0,011$ & $18,8 \pm 0,75$ \\
\hline Agroverm & $23,9 \pm 2,9$ & $4,3 \pm 0,09$ & $0,88 \pm 0,059$ & $18,9 \pm 0,85$ \\
\hline Ribav Extra & $21,6 \pm 1$ & $4,0 \pm 0,21$ & $0,77 \pm 0,023$ & $17 \pm 0,89$ \\
\hline Control & $21,6 \pm 0,3$ & $4,0 \pm 0,39$ & $0,77 \pm 0,024$ & $16,1 \pm 0,85$ \\
\hline \multicolumn{5}{|c|}{ Mixed sowing } \\
\hline $\mathrm{SiO}_{2}$ & $20,3 \pm 1,7$ & $5,1 \pm 0,12$ & $0,91 \pm 0,017$ & $20 \pm 1,29$ \\
\hline $\mathrm{MoO}_{2}$ & $19,8 \pm 0,9$ & $4,8 \pm 0,16$ & $0,88 \pm 0,017$ & $18,2 \pm 1,11$ \\
\hline $\mathrm{Fe}_{3} \mathrm{O}_{4}$ & $19,5 \pm 0,9$ & $5,1 \pm 0,12$ & $0,88 \pm 0,030$ & $19,1 \pm 0,63$ \\
\hline Control & $18,1 \pm 0,9$ & $3,9 \pm 0,15$ & $0,79 \pm 0,028$ & $16,4 \pm 0,74$ \\
\hline
\end{tabular}


Leaf area is one of main factors in increasing the yield of green mass. The maximum leaf area was observed in combined crops in the $\mathrm{SiO} 2$ variant -85.5 thousand $\mathrm{m} 2 /$ ha, and with mixed sowing the highest value was shown in the $\mathrm{SiO} 2$ variants 79.8 thousand $\mathrm{m} 2 /$ ha and $\mathrm{MoO} 2$ - 78 thousand $\mathrm{m} 2 /$ ha. Leaf area in the control variant of mixed sowing was minimal and amounted to 54.7 thousand $\mathrm{m} 2 /$ ha.

Quality and nutritional characteristics of green fodder cannot be expressed by one factor. Such an assessment consists of the following indicators: mineral nutritional value, digestibility of nutrients, energy nutritional value, etc. It was established that the maximum yield of green mass at combined sowing was shown by the $\mathrm{SiO} 2$ variant $-24.8 \mathrm{t} / \mathrm{ha}$, and by the yield of dry matter Fe3O4 - 5.1 t / ha. In mixed crops, the maximum value of the green mass yield is also registered in $\mathrm{SiO} 2$ variant $-20.3 \mathrm{t} /$ ha, and the highest dry matter content is noted in $\mathrm{Fe} 3 \mathrm{O} 4$ variants; $\mathrm{SiO} 2$ and equals to $5.1 \mathrm{t} /$ ha.

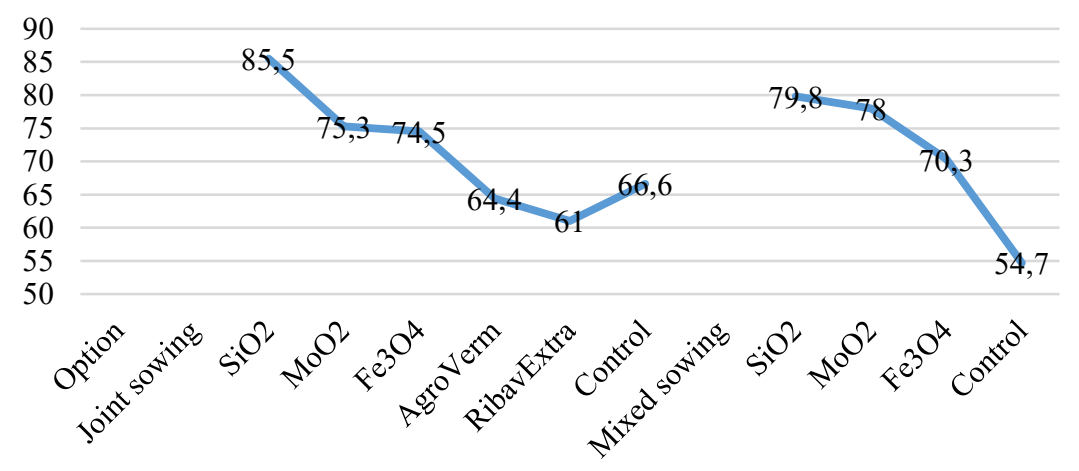

Fig. 1. Productivity of annual crops with combined and mixed crops.

The variant with the use of ultrafine particles $\mathrm{SiO}_{2}$ had $20 \%$ more digestible protein in both sowing methods, low protein content is registered in the control variants $16.1 \% ; 16.4 \%$ respectively. According to the content of feed units per $1 \mathrm{~kg}$ of dry matter, $\mathrm{SiO}_{2}$ variants with 0.91 prevail.

The main task for fodder production is to increase yields and improve the structure of sown areas by expanding multi-species sowing of protein crops with high-energy nutritional value and their mixture with cereals. It is better to cultivate peas in a mixture with cereals such as barley and millet, since they are located according to the vegetative structure and the location of the root system, thereby maximizing the use of soil fertility and environmental factors. [8]

It has been established that the pre-sowing treatment of seeds with ultrafine particles affects the nutritional value of feed, as well as the productivity of crops. Previously, the effect of ultradispersed $\mathrm{Fe} 3 \mathrm{O} 4$ particles on wheat plants was shown; with their use, an increase in seed germination and leaf length was observed. [7] It was established that leaf area in combined sowing was at the highest level, and the largest area was observed with the use of ultrafine particles of $\mathrm{SiO}_{2}-85.5$ thousand $\mathrm{m} 2 /$ ha. The cultivation of mixed and combined sowings of annual forages allows consistently obtaining the maximum yield of green mass with combined sowing, the $\mathrm{SiO}_{2}$ option is $24.8 \mathrm{t} /$ ha, and the dry matter yield Fe3O4 is $5.1 \mathrm{t}$ / ha. In mixed crops, the maximum value of green mass yield was also recorded in $\mathrm{SiO}_{2}$ variant $-20.3 \mathrm{t} / \mathrm{ha}$. The use of ultrafine particles of $\mathrm{SiO}_{2}$ was registered to collect the digested protein in both sowing methods, it equals to $20 \%$ in the variant, the low protein content was registered in the control variants, $16.1 \% ; 16.4 \%$. According to the content of feed units per 1 $\mathrm{kg}$ of dry matter, variants with $\mathrm{SiO}_{2}-0.91$ prevail. 


\section{Conclusion}

In the conducted experiment, it was shown that the pre-sowing treatment of seeds with ultrafine particles had a stimulating effect on growth processes of peas, millet, barley, stimulating the germination energy and germination of seeds, productivity and the nutritional value of green forage.

\section{Acknowledgements}

The studies were carried out in accordance with the state task plan of the SSM2019-0004 NCB countries

\section{References}

1. L. Galaktionova, I. Gavrish, S. Lebedev, Toxicology and Environmental Health Sciences, 11(4), 259 (2019)

2. N. A. Younes, M. F. A. Daud, A. A. Vardani, Chemosphere, 228, 318 (2019)

3. N. Pariona, A. I. Martinez, H. M. Cdu-Garcia, L. A. Cruz, A. Hernandez-Valdez, Saudi J. Biol. Sci., 24, 1547 (2017)

4. M. Rui, S. Ma, Ya. Bely, Yu. Hao, E. Yu. Wang, J. Tan H. Yang, F. Jiang, A. Ali, R. Yukui, W. Cao, Environ. Sci. Nano., 5, 2088 (2018)

5. N. Taran, V. Storozhenko, N. Svetlova, L. Batsmanova, V. Shvartov, M. Kovalenko, Nanoscale Cut. Lett., 12, 60 (2017)

6. G. Koo, J. Wang, Q. Zhang, Ch. Zhu, R. E. B. Shehab, L. Colvin, P. J. Alvarez, J. Braam, Environ Sci Technol., 49, 626 (2014)

7. S. V. Lebedev, A. M. Korotkova, A. E. Osipova, Russ. J/ Plant Physoil., 61(4), 564 (2014)

8. N. I. Kashevarov, D. Yu. Bashkaev, T. A. Sadokhina, Siberian Bulletin of Agricultural Science, 6, 39 (2015)

9. A. S. Shpakov, N. M. Matveeva, M. I. Tarasenko, Adaptive forage production: problems and solutions, 170 (2002) 